\title{
Evaluation of the hepatoprotective activity of an aqueous extract of olive leaves in male albino rats
}

\author{
Enas A. M. Khalil \\ National Organization For Drug Control And Research
}

\begin{abstract}
Olive leaf extract is used for centuries in treatment of various medical purposes. This investigation aims to evaluate the hepatoprotective activity of an aqueous extract of olive leaves against overdose paracetamol .

18 rats were divided into three groups, control , $0.5 \mathrm{gm} / \mathrm{kg} \mathrm{B}$.W. intrapereitoneally (i. p.) paracetamol treated group and rats were given $2.5 \mathrm{gm} / \mathrm{kg} \mathrm{BW}$ i. p. of olive leaf aqueous extract for three consecutive days prior to the administration of paracetamol.

The results indicated that treatment with paracetamol caused a marked significant increase in serum aspartate aminotransferase (AST),serum alanine aminotransferase (ALT)and alkaline phosphatase (ALP) accompanied by severe congestion of central and hepatic portal veins, vacuolization and ballooning also, a lot of pyknotic nuclei were detected with many small necrotic areas of hepatocytes. Meanwhile group treated by olive leaf extract followed by paracetamol displayed significant reduction in serum (AST),(ALT)and (ALP)associated with nearly normal hepatocyte architecture.

In conclusion, an aqueous extract of olive leaves has antioxidant property could protect against liver damage occurred by overdose paracetamol in male albino rats.
\end{abstract}

\section{Introduction}

Olive leaf extract is traditionally used to relieve fevers, malaria and in the treatment of mild to moderate hypertension (Weiss, 1988). More recently, it was found that olive leaf extract lowers blood pressure (e.g. systolic and diastolic) and dilate the coronary arteries surrounding the heart ( Petokov and Manolov, 1972 \& Khyyal, et al., 2002 ), inhibits the oxidation of LDL and the development of atherosclerosis (Visioli and Galli, 1994 \& Somova et al, 2003), has antibacterial activity (Fleming et al,1973), antimicrobial effect (Markin, et $a l, 2003$ ), antiviral properties (Heinze et al, 1975), reduces blood sugar (Peirce, 1999), enhances the immune system (Kubo, et al, 1985), has hypouricemia effect (Departement of Pharmacology and Toxicology, Society of Pharmaceutical Industries of Tunis, 1994), has antidiarrhea effect (Duke, et al, 2002) can provide effective and cheap source to treat hypertention,complicated by stenocardia and cardiac failure (Somova et $a l, 2003$ )

Olive leaf extract has a wide number of constituents, including 4types of triterp- enoid derivatives, namely (oleanolic acid, ursolic acid ,uvaol and methyle maslinate) (Somova, et al,2004) and several types of flavonoids (e.g. rutin, apigenin and luteolin) (Bruneton, 1995).

(Buttar et al, 1976) reported that hepatocellular damage and impaired liver function, occurred following administration of single doses of 0.5 and $1 \mathrm{gm} / \mathrm{kgB}$.W. of paracetamol in rats.

This investigation aims to evaluate the hepatoprotective activity of an aqueous extract of olive leaves against overdose paracetamol.

\section{Materials and Methods}

\section{Plant material}

Olive leaves were obtained from the trees cultivated in the front of Alexandria Library. The leaves were dried and well ground. 200ml of boiling distilled water were added to $7 \mathrm{~g}$ powder olive leaves, left for 10 minutes and filtered .The filtrate were dried in an incubator at $35-40 \mathrm{c}^{\circ}$. The residue was given to rats in a dose 
equivalent to human therapeutic dose (Paget and Barnes, 1964) .

\section{Animals}

18 adult male albino rats weighing 120-150g were purchased from Helwan farm .The animals were housed under good hygienic condition and water excess.

\section{Experimental design}

The animals were divided into three groups consisting of six animals .Group I ,served as control, group II (over fasted animals) was given paracetamol $(0.5 \mathrm{~g} / \mathrm{kg}$ B.W. i.p.) and group III was given olive leaf aqueous extract $(2.5 \mathrm{~g} / \mathrm{kg}$ B.W. i.p.) for three consecutive days prior to the administration of paracetamol .

\section{Blood sampling}

After 48 hours from paracetamol administration, blood samples were collected from retro-orbital vein in all groups. The blood was allowed to collect at room temperature and serum obtained after centrifugation was used for determination serum aspartate aminotransferase, alanine aminotransferase (Reitman and Frankle,1957) and alkaline phosphatase (German Society for clinical chemistry, 1972).

Fresh liver samples were collected in formalin $10 \%$ and stained with $\mathrm{E} \& \mathrm{H}$.

Statistical analysis.

All data obtained were analyzed using student ' $t$-test according to Sendecor and Coebram (1969).

\section{Results and Discussion}

Table(1) displayed marked significant elevation in serum (AST),(ALT) and (ALP) in paracetamol treated group accompanied by congestion of central vein ,vacuolization and small areas of many pyknotic nuclei were observed. Debris of cytoplasmic organoid were noticed with enlarged nuclei of endothelial lining of central vein (fig.3) compared to normal control (fig.2). Congested hepatic portal vein and dilated bile canaliculi with dilated sinusoidal spaces were observed (fig.4). The hepatic cellular damage and impaired liver function by paracetamol treatment may be as the result of lipid peroxidation with its numerous toxic oxygen free radicals on the biological membranes of the liver, and cause hepatocyte necrosis . The liver unable to transport fat from and to the liver .Fat droplets appear to accumulate in the hepatocytes. Treatment of aqueous extract of olive leaves prior the administration of paracetamol preventing free radical generation and stopping the resulting damage occurred in the hepatocytes. Serum AST, ALT and ALP appear normal levels, and this was accompanied with normal architecture of hepatocytes and central vein , while few cells appeared faintly stained (fig.5) .

The hepatoprotective effect of aqueous extract of olive leaves may be due to its antioxidant property (Peirce,1999).The phenolic structure of olive leaf extract(Briante,etal,2002) helps to reduce the free radicals which, resulted from hepatotoxin paracetamol.

Farag et al,(2003) reported that free and total polyphenolic compounds extracted from olive leaves are safe on serum(AST),(ALT).

In conclusion, an aqueous extract of olive leaves has antioxidant property which can protect liver damage occurred by overdose paracetamol in male albino rats.

\section{Legend of figures}

Fig.2: Normal rat liver $\quad H \& E$ x 100

Fig.3: Liver of paracetamol treated rat showing congestion of central vein , vacuolization and small areas of many pyknotic nuclei were observed .Debris of cytoplasmic organoid were noticed with enlarged nuclei of endothelial lining of central vein. Inflammatory cells, fatty droplets were scatters in the hepatocytes

H \&E x 400

Fig.4: Liver of paracetamol treated rat showing congested hepatic portal vein and dilated bile canaliculi with dilated sinusoidal spaces H\&E x 400

Fig.5: Liver of paracetamol and olive leaf extract treated rat showing normal architecture of hepatocytes and central vein, while few cells appeared faintly stained

$\mathrm{H} \& \mathrm{E}$ x 100 
Evaluation of the hepatoprotective activity of.........

Table1: Effect of olive leaf aqueous extract on serum enzymes in rats treated with hepatotoxic dose of paracetamol

\begin{tabular}{|c|c|c|c|}
\hline \multirow{2}{*}{ Groups } & \multicolumn{3}{|c|}{ Parameters } \\
\cline { 2 - 4 } & AST & ALT & ALP \\
& U/L & U/L & U/L \\
\hline Control & 39 & 24 & 80 \\
& \pm 1.5 & \pm 2.1 & \pm 3 \\
\hline Paracetamol & $91^{* * \star} \uparrow$ & $80^{* * \star} \uparrow$ & $150^{\star * *} \uparrow$ \\
& \pm 4.2 & \pm 3.8 & \pm 4.8 \\
\hline Olive leaf + Paracetamol & 45 & 32 & 97 \\
& \pm 2.5 & \pm 3 & \pm 4.2 \\
\hline
\end{tabular}

Number of rats in each group $=6$ ${ }^{* * *} \mathrm{P}<0.001$

Fig 1 : Effect of olive leaf extract on serum enzymes in rats treated With paracetamol

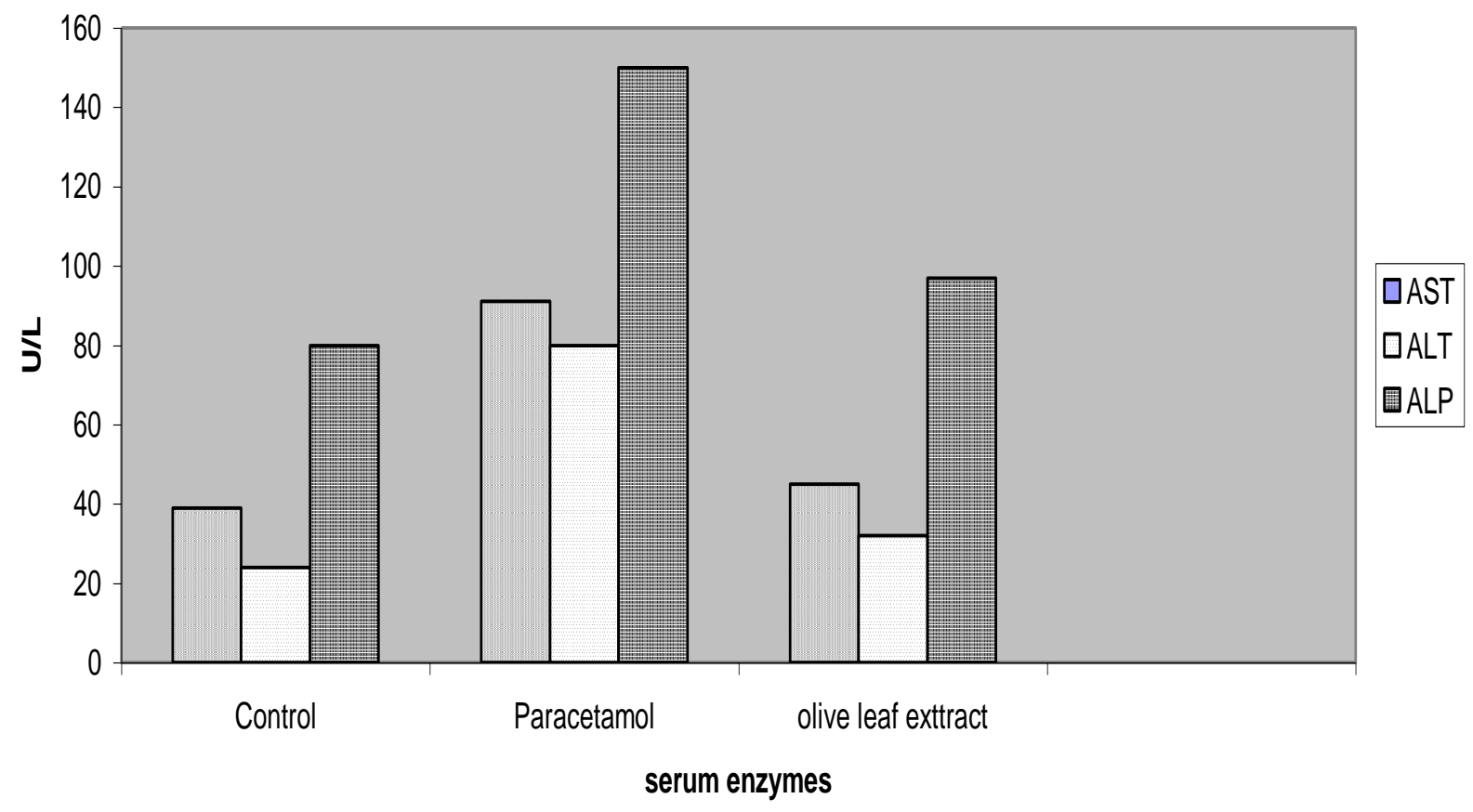


Enas A. M. Khalil
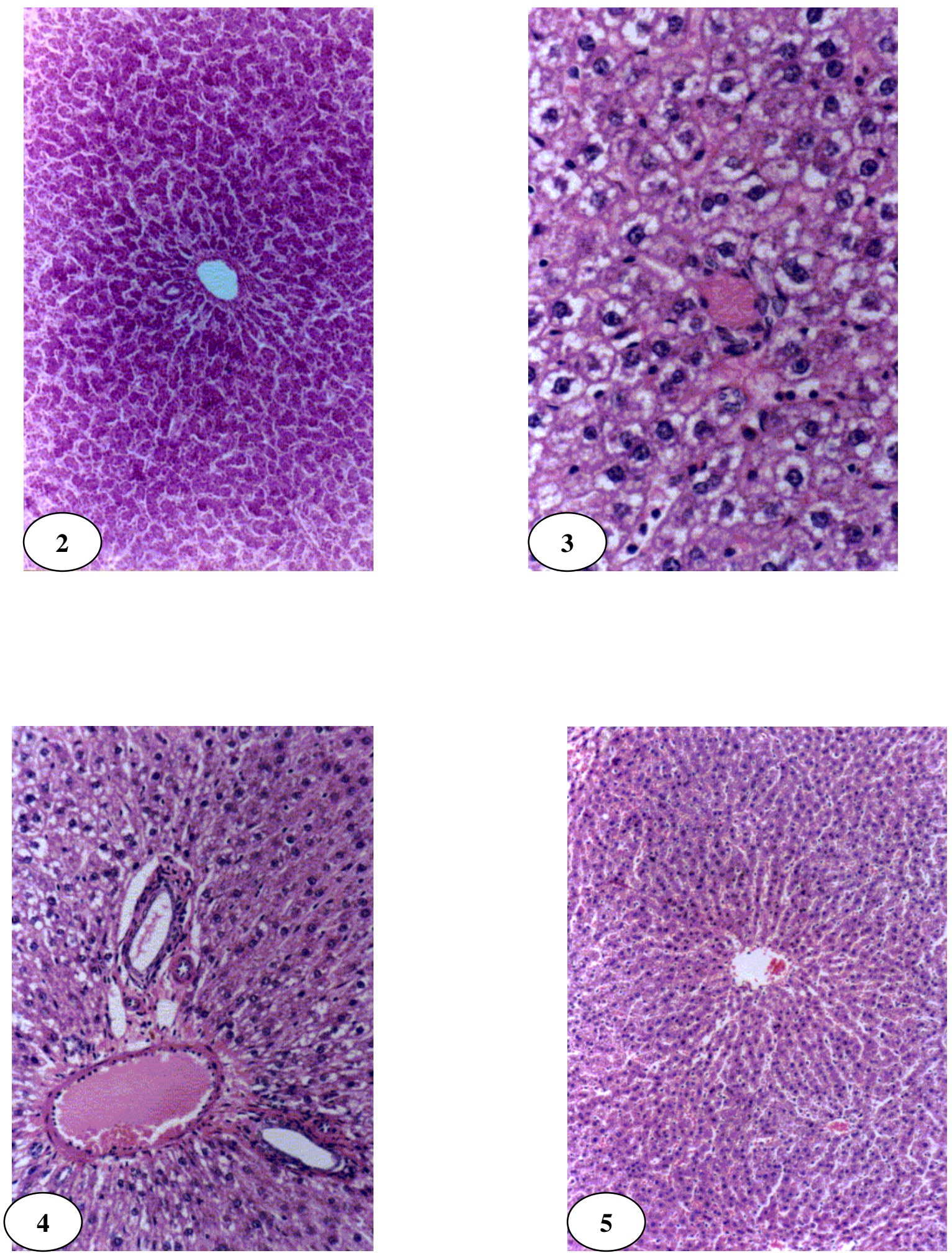


\section{References}

1. Briante,R;Patumi,L.;Tereniziani,S;Bism uto $E$ and Febbraio,F.(2002):Olea europaea L.leaf extract and derivatives :antioxidant properties. J.Agric.Food Chem.,50(17): 4934.

2. Bruneton,J.(1995): Pharmacognosy, Phytochemistry ,Medicinal Plants.Paris, France: Technique \&DocumentationLavoisier, 487

3. Buttar,H.S.;Nera,E.A.and Downie,R.H .(1976): Serum enzyme activities and hepatic triglyceride levels in acute and subacute acetaminophen-treated rats. Toxicology ,6:9.

4. Departement of Pharmacology and Toxicology, Society of Pharmaceutical Industries of Tunis,(1994): Hypotension hypoglycemia,and hypouricemia recorded after repeated administration of aqueous leaf extract of Olea Europaea,Belgian Pharmacology Journal,Mar.-Apr.;49(2):101

5. Duke, J.A.; Codwin, M.J. and Cillier, J.(2002):Hand Book of Medicinal Herbs CRC press P.296

6. Farag,R.S.;El-Baroty,G.S.and Basuny, A.M. (2003): Safty evaluation of olive phenolic compounds as natural antioxidants.Int.J.Food .Sci.Nutr. 64(3):159

7. Fleming, H.P.;Walter, W.M.and Etchells,J.L., (1973): Antimicrobial properties of Oleuropein and products of its hydrolysis from green olives. Applied Microbiol.:26:777

8. German Society for clinical chemistry (1972):Standard method for clinical chemistry ,standard method for determination of alkaline phosphatase (ALP) activity J.Clin.Chem.Clin.Biochem, ,290

9. Heinze,J.E.; Hale,A.H.and Carl,P.H. (1975): Specificity of the antiviral agent calcium elenolate .Antimicrob.Agent Chemther.:8(4),421

10. Khayyal, M.T.,El-ghazaly, M.A.; Abdallah D.M.;Nassar,N.N.and Kreuter, M.H (2002): Blood pressure lowering effect of an olive leaf extract (Olea europaea) in L-Name induced hypertention in rats . Arzneimittelfors chung; 52(11):797

11. Kubo, I. (1985): A multichemical defense mechanism of bitter olive olea europaea ( Oleaceae)- is oleuropein a phytoalxin precursor? J.Chem.Ecol.;238:277

12. Markin, D. ;Duek,L.and Berdicevsky, I.(2003):In vitro antimicrobial activity of olive leaves .Mycoses.,46(3-4):132

13. Reitman ,S. and Frankle,S.(1957) : A colorimetric method for determination of serum glutamic oxaloacetic and glutamic pyruvic transaminases .Am. J. Clin Path.28:56

14. Sendecor, G.W. and Coebram, W.C., (1969): In "statistical Methods "6 ${ }^{\text {th }}$ ed Iowa State Univ. Press Anes, Iowa, U. S.A. P.70

15. Somova,L.I.;Shode,F.O.;RamnananP, and Nadar,A. (2003): Antihypertensive ,antiatherosclerotic and antioxidant activity of tripenoids isolated from Olea europaea,subspecies Africana leaves.J .Ethnopharmacol, 84(2-3)299

16. SomovaL.I.;Shode,F.O.and Mipondo,M. (2004): Cardiotonic and antidysrhythmic effects of oleonolic and ursolic acids ,methyl maslinate and uvaol.Phytomedicine , 11(2-3);121

17. Paget, G. E. and Barnes, J.M.(1964):"In toxicity tests" Vol.(1). Chapter (6) P.135, Editor: Laurance, D.R. and A. L. Academic Press, London, New York.

18. Peirce, A.(1999): Practical Guide to Natural Medicines. New York. William Morrow and Co.,P.469.

19. Petokov,v and Manolov,P.(1972): Pharmacological analysis of the iridoid oleuropein.Arzneim Forsch/ Drug Research; 22:1476.

20. Visioli, F.and Galli,C. (1994):Oleuropein protects low density lipoprotein from oxidation .Life Sciences;55:1965

21. Weiss, R.F., (1988):Herbal Medicine, Gothenburg. Sweden: AB Arcancum, p.160 


\title{
تقييم فاعلية المستخلص المائى لأوراق الزيتون لحماية الخلايه الكبدية في ذكور الجرذان الزيت
}

\author{
أيناس على مهدى خليل \\ الهيئة القوميه للرقابه و البحوث الدئ خلئ الئيه
}

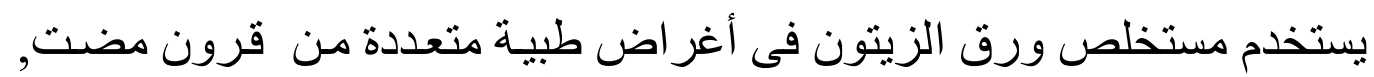

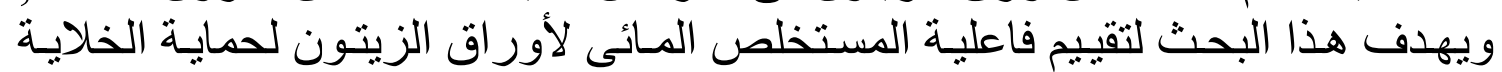

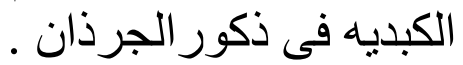

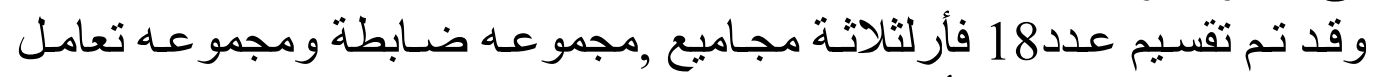

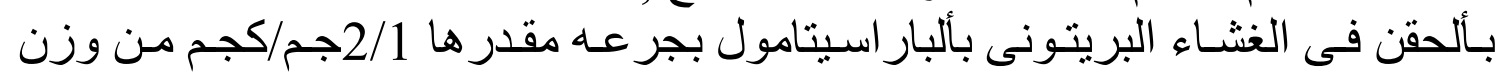

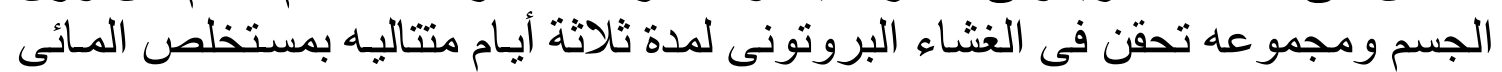

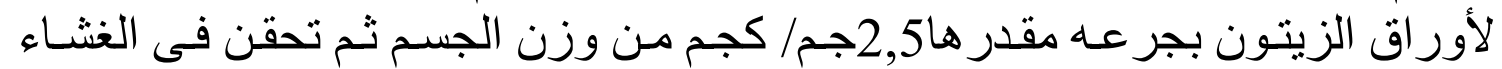

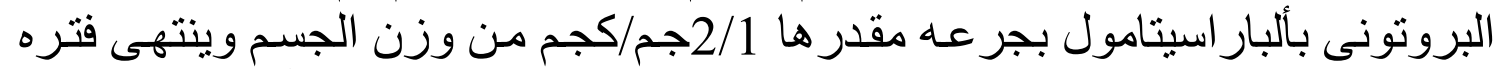

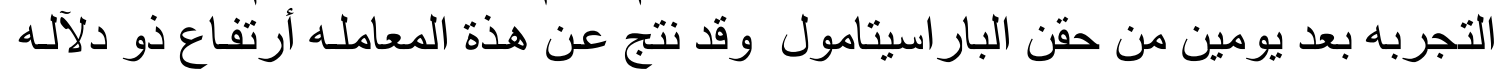

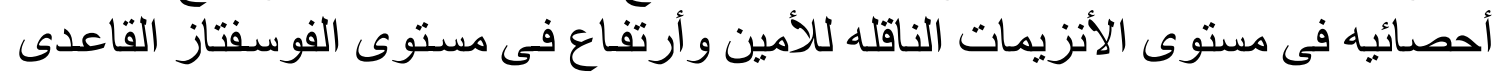

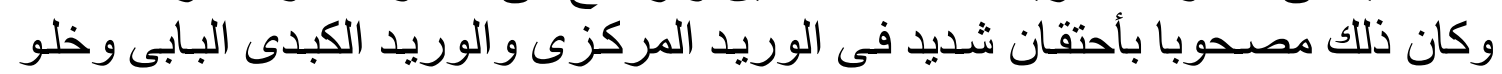

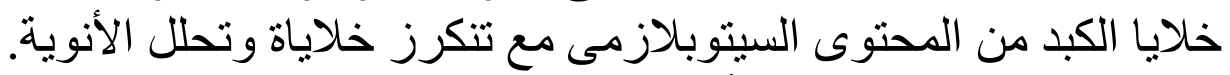

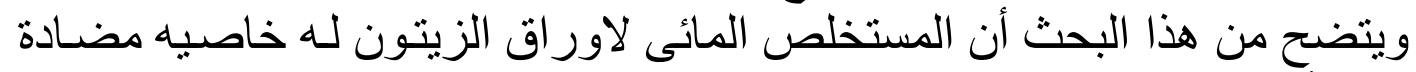

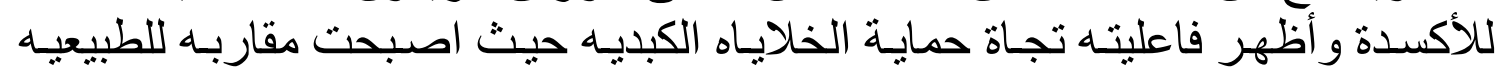
و انخفضت الأنزيمات الكبديه أنخفاض ذاءه ذو دلآله أحصائيه. 